Research Article

\title{
Qualification Enhancement in Intellectual Property for the Teaching Staff of Institutions of Higher Education
}

\author{
Vadym Luniachek $\left(D,{ }^{1}\right.$ Oleksandr Kulakovskyi ${ }^{D},{ }^{1}$ Alla Brovdii $(D), 2$ \\ and Tetyana Varenko $\mathbb{D}^{3}$ \\ ${ }^{1}$ Creative Pedagogy and Intellectual Property Department, Ukrainian Engineering Pedagogics Academy, Kharkiv 61003, Ukraine \\ ${ }^{2}$ Department of Legal Support of Economic Activity, O.M. Beketov National University of Urban Economy in Kharkiv, \\ Kharkiv 61002, Ukraine \\ ${ }^{3}$ Department for Cooperation with International Agencies and Financial Institutions, Kharkiv City Council, \\ Kharkiv 61200, Ukraine \\ Correspondence should be addressed to Tetyana Varenko; t.k.varenko@gmail.com
}

Received 24 February 2021; Accepted 24 July 2021; Published 3 August 2021

Academic Editor: Bernhard Schmidt-Hertha

Copyright (c) 2021 Vadym Luniachek et al. This is an open access article distributed under the Creative Commons Attribution License, which permits unrestricted use, distribution, and reproduction in any medium, provided the original work is properly cited.

\begin{abstract}
The paper substantiates the need and importance of cultivation of a competence in intellectual property rights (IPR) protection in the teaching staff in higher education during their qualification enhancement (QE) as a condition for their further development and provision of quality higher education in Ukraine. The survey was conducted under the state-funded R\&D topic to evaluate the attitude to intellectual property among the teaching staff of institutions of higher education (IHE). It looks into the factors and mechanisms of IPR protection and inclusion in the QE programmes for the IHE teaching staff. Knowledge in IPR protection encourages creation of a favourable environment for intellectual activity development, where an important role in its dissemination belongs to the teaching staff. The findings reveal that acquisition of such knowledge and skills is currently not commonly included in the corresponding QE programmes, while the number of those interested in them is significant. Another red flag in this regard is overbureaucratization of the process and the working overload of the teaching staff. Therefore, changes are in order in the QE programmes to include the relevant portion of knowledge and training in IPR, their exercise, protection, and commercialization.
\end{abstract}

\section{Introduction}

The transformational processes taking place in the world economy require improvement of means and ways for the state to achieve the economic goals. Today, the intellectual capital is becoming the driving force of the necessary transformations in all spheres of the state's activity and is the foundation for its competitiveness at the global level. The indicators of the state's effectiveness in this direction are respect for intellectual property rights (IPR), exercise of the policy of intolerance towards violations thereof, creation and implementation of effective preventive mechanisms to ensure observance of such rights, cultivation of understanding of ways, and processes to commercialize intellectual property assets and the importance of these tools for the state's participation in economic relations.

Adult education (the important components of which are postgraduate education, retraining, and qualification enhancement (QE) of the teaching staff, as defined by the Law of Ukraine "On Education") is a constituent of life-long learning and aims to ensure the right of each adult person to such learning with regard to their personal needs, priorities of social development, and needs of the economy. Knowledge in the field of intellectual property is a necessary element of development of the civil society, the law-governed state, and its economic well-being. Therefore, an important indicator of the society's development is provision of quality educational services that meet the requirements of the 
labour market and cultivate respect for human rights and freedoms, which, inter alia, include IPR. In this regard, the priority task is development of the intellectual property competence in the IHE teaching staff, who, on the one hand, are agents of legal relations in the field of intellectual property and, on the other hand, have to ensure cultivation of the intellectual property competence in students during their professional training.

As noted by Storozhenko and Nimko, it is not uncommon for agents of the scientific, technical, and economic activity to voluntarily refuse to use the existing mechanisms of protection of their rights and interests as owners of intellectual achievements and works due to their low legal and economic culture [1]. The capital of education (knowledge), the capital of professional training (qualification, skills, abilities, and work experience), and the awareness of new information are the triad of six types of elements in the structure of the human capital, according to the founder of the theory of human capital Becker [2].

This research focuses on intellectual property qualification enhancement of the staff at institutions of higher education (IHE), their attitude to violations in this field, and the need of knowledge in the field of intellectual property rights protection. The research was conducted in compliance with the current legislation of Ukraine, scientific developments of researchers, and the survey of 180 educators working at institutions of higher education the results of which are presented in this paper as follows.

The main directions for the questions set within this study are as follows: (1) attitude to violations of intellectual property rights; (2) reasons for and motivation behind violations of intellectual property rights; (3) qualification enhancement in intellectual property rights; (4) intellectual property rights protection management. The questions within these directions aim at revealing their essence. For instance, to explore the direction of qualification enhancement in intellectual property, the respondents were asked about their interest in such qualification enhancement, its most effective forms, and the public authority that should be responsible for it.

The study conducted was conditioned by the negative tendencies in development in both the system of education and various areas of economy of Ukraine. In particular, according to USTR Special Report No. 301 for 2020 [3], our state is one of the ten countries with the worst situation in the field of intellectual property rights protection. We believe that one of the most important factors to have positive impact on improvement of the situation with property rights protection is cultivating a relevant competence in the teaching staff working at institutions of higher education. Executing their professional duties, they act as holders of copyright and related rights and cultivate the corresponding competences in their students.

Considering the previously mentioned, the questionnaire was designed with the aim to study the existing problems that have a negative impact on the state of intellectual property rights protection within the legal relations in which educators of institutions of higher education participate and to determine their attitude to such competence cultivation during qualification enhancement in intellectual property rights.

The authors of this study set for themselves the following tasks: (1) determining the attitudes to violations of intellectual property rights; (2) determining the reasons for and motivation behind violations of intellectual property rights; (3) substantiating qualification enhancement in intellectual property rights; (4) proposing a model technology for qualification enhancement in intellectual property rights.

The purpose of this research is to reveal and substantiate the need to develop a competence in IPR protection in the teaching staff in higher education during their $\mathrm{QE}$ as a prerequisite for their further development in the innovative society and as a component of quality education services within the internal quality assurance systems in IHE.

\section{Analysis of Research and Publications}

IPR exercise and protection in education and the procedural aspects of QE in this field are limited in their presence in the national scientific sources. At the same time, further development of civilised market relations in Ukraine has put this issue on the agenda as a precondition for further innovative development of the country.

Orliuk draws the attention to the fact that "Ukraine needs to provide the national labour market with professionally trained specialists who have knowledge in various fields, and that of intellectual property therewith" [4]. The scholar also emphasises the need to organise courses professional training in the field of intellectual property for the teaching staff of institutions of higher education (IHE) in various specialities in order to increase their professional potential [Ibid.]. V.V. Oliinyk studied QE models for the IHE teaching staff with focus mostly on the priority of education development that systematically develops the quality of the modern society via the basic personality values recorded in the European Union Charter, intellectual property right occupying an important place among them [5].

The monograph "an academic's intellectual property right" focuses on an academic's IPR to official works. It looks into the essence and content of the intellectual property right to an official work, the procedure of its emergence, its acquisition and exercise, and the forms and ways of protection of such rights [6]. Yet, the content and significance of such competence cultivation were not the subject of research there.

Isaienko concludes that raising the level of legal culture among the academic and teaching staff throughout life is one way of ensuring the quality, efficiency, and effectiveness of research and teaching and productivity of the intellectual activity through legal training in postgraduate pedagogical education [7]. Korohod maintained that a special role in the intellectual property policy, which is an important constituent of IHE activity, belongs to creation of a system that would encourage creative and inventive activity among the academic and teaching staff as a substantial foundation for their professional self-realization lies in continuous QE and development of professional skills [8]. Redchyts considered 
the ability of educators and scientists to observe the copyright when using intellectual property assets as one of the components of the ICT competence of the teaching staff [9].

Our previous works addressed the status of an educator as an agent of intellectual property, emphasised the need for special courses and seminars to be conducted for them, and observed that only a limited number of IHE in Ukraine today can ensure a quality academic process on this topic. Institutions of postgraduate pedagogical education have no such specialists at all. Therefore, the urgent requirement of the time is to introduce relevant disciplines in the last year of undergraduate pedagogical IHE by analogy with most technical IHE, where the discipline is part of the curriculum [10]. The staff of the Department of Creative Pedagogy and Intellectual Property turned to the problems of development of competences in the field of intellectual property in their scientific works, too $[11,12]$. Moreover, significant attention was devoted to the study of the models of the system of postgraduate pedagogical education in the context of the new law of Ukraine "On Education" adopted in 2017 and providing for diversification of postgraduate pedagogical education and ensuring the possibility of its development in the context of globalization trends [13].

Tolochko looked into the general competences of the academic and teaching staff of the system of postgraduate education and pointed out knowledge of the theoretical and methodological foundations of intellectual property relations regulation as part of the research competence. He also defined the essence of the competence in information transfer as one including, but not limited to, the ability to search, select, and process information from sources and literature on intellectual property issues [14].

The World Intellectual Property Organization examined the problem of dissemination of intellectual property knowledge in the countries with economies in transition. The emphasis is mainly on law students and legal practitioners, but nonlegal specialists, including scientists, are not left out. The conclusion of this study is that such specialists' training should cover protection of IPRs to self-created objects, as well as legality of use of intellectual property assets of other authors and inventors [15].

The legal scholars mostly explore the aspects related to establishment of a system of IPR protection and its legal support, including legal relations between and in relation to the academic and teaching staff [16-19].

Foreign studies devote considerable attention to introduction of the intellectual property discipline in the IHE curricula. Some also consider the need to include intellectual property topics in QE courses. Thus, clearly traceable is the idea that inclusion of intellectual property teaching in the university curricula is seen as one of the most important issues for consolidation of a culture of respect for IPRs in society as well as for promotion of the national policy in science, technology, and innovation. The practices of teaching intellectual property at the Unicamp research university bring about the conclusion that intellectual property is not yet widespread under the bachelor's degree programme, much less under the postgraduate programmes and in competence development courses [19].
The mission of universities is to create knowledge and provide high-level socially significant educational services. The knowledge and intellectual capital of a university have become a strategic resource and a key competence in gaining of a competitive advantage in the international competition. Reviewing the practices of universities around the world in the context of intellectual capital development, Alkhateeb et al. concluded that only universities in the developed countries of the world pay attention to the intellectual capital, while the use of such capital by universities in other countries is still under development [20]. The study provides no data on the situation in Ukraine. However, the situation in the domestic universities remains at the initial stage of development. In our opinion, this is due to lack of the relevant knowledge in the field of intellectual property and technology transfer in the academic and teaching staff of IHE, which find confirmation in the results of our research presented as follows.

Studying intellectual property education for inventors, Soetendorp revealed the problems of knowledge acquisition in the systems of general secondary education and higher education during the training of engineers and the possibility of self-education. He pointed out that engineers, like most scientists, are rightly reluctant to stand before their students before teaching unfamiliar topics. Ignorance is easy to use as an excuse for rigid control within disciplinary guidelines when ignorance is actually an effective starting point for promotion learning. In this regard, the scholar considers it necessary to use transdisciplinary links to expand and develop knowledge in the field of intellectual property. According to him, changes in the knowledge economy are rapid for both students and scientists. The need to include intellectual property disciplines in the curricula of nonlaw students should be seen as an opportunity to address a vital topic linking commercial, legal, and technical disciplines [21].

Having considered the problems of cultivation of a culture in the field of intellectual property, Najafov concluded that the failure to cultivate such a culture in IHE students undermines the development of their scientific potential and hampers their scientific creativity [22]. Thus, the problem of knowledge development in the field of intellectual property and use of intellectual capital is acute in both Ukraine and other countries of the world. However, it should be noted that many issues remain unresolved in the literature. One of them in particular is that of $\mathrm{QE}$ in this area of IHE academic and teaching staff. No studies seem to rely on the indicators of the current state of knowledge in the field of intellectual property.

A study by the Japan Patent Office emphasises the growing need for education in intellectual property maintaining that promotion of knowledge and $\mathrm{QE}$ in this field are more relevant today than ever. This is conditioned by the development of our society, which is approaching the fifth stage of its transformation: (1) Society 1: Hunting and Gathering; (2) Society 2: Agriculture; (3) Society 3: Industry; (4) Society 4: Information; (5) New Society: Society 5.0. To promote education, disseminate knowledge, and improve the level of the intellectual property competence, it is 
important to train educators who can perform these tasks. However, the only training school teachers currently receive covers but the basic academic skills. As a result, the level of knowledge about this new field of intellectual property among the teaching staff is the same as that of the general public. It will take a lot of time and work to raise the knowledge of most educators to a level sufficient enough to teach others [23].

A study of the level of knowledge in intellectual property of the teaching staff was conducted at the University of Cebu Lapu-Lapu and Mandau (Philippines). A specifically designed questionnaire was used to measure the teaching staff's awareness of intellectual property and their rights. The study consisted of two parts. One was establishing the profile of a teaching staff member. The other was determining the teaching staff's familiarity with the following six areas: patents, utility models, industrial samples, geographical indications, trademarks, and copyrights. The findings brought about the conclusion about the lack of knowledge of the teaching and academic staff in the field of intellectual property and the need to increase their level in this regard [24].

Improving the level of knowledge in the field of intellectual property is possible through e-newsletters and booklets, internet programmes, games, and other software as well as by dissemination of information about them. University education should ensure acquisition of knowledge on intellectual property as it is through this rite of passage that future authors of and participants in professional start-ups receive their professional training [25].

The process of education reformation in Ukraine is an important step towards establishment and development of the knowledge economy. Thus, the draft National Strategy for Intellectual Property Development in Ukraine, inter alia, emphasises the need to disseminate intellectual property knowledge, train, and enhance the qualification of specialists in the field of intellectual property. In particular, it maintains that acquisition of intellectual property knowledge in higher education will create conditions for development of a society that understands the value of own achievements and benefits obtainable through innovation and exercise of rights to the results of their own creativity; it will encourage innovation and commercialization and, most importantly, ensure professional support of instrumental application of IP rights as a target component of the innovation policy, high-quality provision of protection of IP rights [26].

Acquisition of IP competences in the higher education system will help bring together education, science, and industry in order to prepare the competitive human capital for high-tech and innovative development of Ukraine, ensure personal self-realization, and meet the needs of the society, the labour market, and the state in qualified specialists. It will also contribute to international integration and that of Ukraine's higher education system into the European Higher Education Area and the European Research Area. Such education should promote cultivation of a creative way of thinking in young people who are able to create and solve complex interdisciplinary tasks, responding to the existing public demand in an effective and timely manner.
Moreover, the need to raise awareness of innovators in the field of legal IPR protection is emphasised in the $\mathrm{Na}$ tional Strategy for Intellectual Property Development in Ukraine for 2020-2025 [Ibid.].

According to the strategy, lack of quality education in intellectual property for all is an urgent problem today. Ukrainian IHE currently have no disciplines on IP adapted for the corresponding specialities, which would contribute to IP knowledge acquisition not only at the level of specialised master's degree programmes in IP (law, management), but also for other specialities, including those at the bachelor's degree level.

Ukraine has no joint master's degree programmes in IP with WIPO, either. Nor there is ongoing work on training and $\mathrm{QE}$ of the teaching staff involved in teaching intellectual property courses both under specialised master's degree programmes and as intellectual property disciplines in various fields of knowledge in general.

On the positive side, in 2018, the Ministry of Education and Science of Ukraine initiated the practice of seminars on exercise and protection of IPRs and their commercialization that target the staff of institutions of higher education and research institutions. To promote innovation culture and encourage academic entrepreneurship and commercialization of IP assets, the Ministry of Education and Science in cooperation with the government, foreign organizations, and other stakeholders launched the practice of trainings. In particular, on 21 May 2019, the training "Best Practices Education for Entrepreneurship: Creative Teaching Methods" was organized by the NGO "Innovation Partnership Platform" with the support of the Ministry of Education and Science of Ukraine and the Ministry of Foreign Affairs of Estonia [27].

At the same time, the sources analysed indicate lack of attention to empirical research on cultivation of a competence in IPR protection in the IHE staff in Ukraine.

It is worth mentioning that sociological studies of the problem of intellectual property qualification enhancement in educators at institutions of higher education in Ukraine have never been conducted. Our study was the first, which strengthens its relevance and importance. The previous study based on the results of another survey aimed at determining the state of compliance with the academic integrity rules [28].

As for the problem of observing the intellectual property rules, the situation in Ukraine is such that all the research in this field has been fragmentary. In particular, some problem aspects in adherence to the intellectual property rules are reflected in the dissertation by I. Lytvynchuk [29, p. 326], who looked into the problems of intellectual property protection in the agrarian sector of Ukraine relying on the results of a survey conducted among the specialists, who combine their research with other types of activity, because this is the group which researchers in higher education (faculty members) are included with. The sampling population was 570 respondents, or $1 \%$ of the general population. Answering the question about the main obstacles in the path to creating an effective system for intellectual property rights protection in Ukraine, $13.1 \%$ pointed out 
that the main problem was the low level of legal awareness in intellectual property matters. This level is determined by the body of knowledge, skills, and abilities an individual has in the relevant field. Moreover, an interesting response was that regarding the main factors influencing the creative activity in agrarian economy. According to $15.1 \%$ of the respondents (which is the second largest result in the survey), this is the level of education.

Outside of Ukraine, studies of the problem of intellectual property were conducted, but qualification enhancement for educators in higher education has never been the in focus thereof. One such research, its results published in 2009, relied on the answers of the lecturers of technical disciplines and a few students to determine their knowledge in intellectual property. The second part of this study explored the practical skills in intellectual property rights protection [29].

Other studies covered the students' attitude towards intellectual property [30]. Another survey aimed to explore the general understanding of the rights in intellectual property and innovation research by the educators of the Institute of Electrical Engineering and Radio Electronics [31].

Thus, the previously mentioned analysis enables us to conclude that the problem of intellectual property qualification enhancement among the educators in higher education has not been studied yet. Therefore, the results of this survey can be used as the baseline indicators for further research in the field.

\section{Materials and Methods}

This research paper presents the results of the pilot sociological survey "intellectual property through the eyes of educators" conducted by the Department of Creative Pedagogy and Intellectual Property of the Ukrainian Engineering Pedagogics Academy in cooperation with the sociologists of V.N. Karazin Kharkiv National University under the state-funded R\&D topic No. 19-01 DB "theoretical and methodological foundations of $\mathrm{QE}$ of the teaching staff of the education system in the field of intellectual property" awarded on a competitive basis to evaluate the attitude of the IHE teaching staff to intellectual property, including the context of their study of the factors and mechanisms of IPR protection during their $\mathrm{QE}$ under diversification of the educational services in this area. The survey was conducted from May to December 2019 and consisted of three stages: (1) preparatory (May-June 2019); (2) field (July-October 2019); (3) final (November-December 2019). The findings were submitted in the analytical report "intellectual property through the eyes of educators" (under code DK-021: 201597320000-3) executed under contract No. 87-II dated 27 May 2019 (33).

The survey took place among the teaching staff of four different in type institutions of higher education, which are the largest in the city of Kharkiv and different in their profile of professional training thus ensuring coverage of different curricula. These were a classical university (V.N. Karazin Kharkiv National University), a technical university (Kharkiv National University of Radio Electronics) that specializes in training of IT professionals, an engineeringpedagogical academy (Ukrainian Engineering Pedagogics Academy), and a medical academy (Kharkiv Medical Academy of Post-Graduate Education). At each of these institutions of higher education, the survey covered different areas of training at the level of their schools. Particularly, the selected were ten schools of V.N. Karazin Kharkiv National University, four schools of the Ukrainian Engineering Pedagogics Academy, three schools of Kharkiv National University of Radio Electronics, and one school of Kharkiv Medical Academy of Post-Graduate Education. One department was chosen from each school for continuous selection of the teaching staff for the survey. The method of selection applied was that of probability sampling.

This choice is conditioned by the need to obtain a more complex understanding of the problem under study and to cover extensive audience of the teaching staff specialising in various areas of knowledge and acting as actors in intellectual property relations within the framework of their professional activity. As a result, the findings most fully reflect the state of compliance with intellectual property rights and the problem of qualification enhancement in this sphere.

The questionnaire of the survey was completed by 180 IHE educators. The survey was conducted in four different Kharkiv IHE types and profiles: a classical university, a technical university specialising in IT training, an engineering-pedagogical academy, and a medical academy. Each IHE covered differently specialising university schools, in particular, ten at V.N. Karazin Kharkiv National University (KKNU), three at Kharkiv National University of Radio Electronics (KNURE), four at the Ukrainian Engineering and Pedagogics Academy (UEPA), and one at Kharkiv Medical Academy of Postgraduate Education (KMAPO). One department was chosen at each school where a continuous selection of the teaching staff for participation in the survey was applied.

The research results, its stages, methods, tools, and characteristics of the sampling population are detailed in the analytical report "intellectual property through the eyes of educators" [32] conducted in 2019 by the Department of Creative Pedagogy and Intellectual Property of the Ukrainian Engineering Pedagogics Academy and the sociologists of V.N. Karazin Kharkiv National University. The research of this direction contributes to implementation of effective reforms because it reflects the real state of things in the corresponding field. The lack thereof conditioned the choice of the selected topic, tools, method, and information analysis.

The questionnaire was developed by the specialists of the Department of Creative Pedagogy and Intellectual Property of the Ukrainian Engineering Pedagogics Academy in cooperation with Full Professor of the Department of Sociology, School of Sociology, V.N. Karazin Kharkiv National University, V.M. Nikolaievskyi.

During the execution of the survey, the quality was controlled for the tools (pretest), questionnaire, compliance with the respondent selection rules, logical correctness control of the questionnaire, and other means to ensure 
reliability of sociological information. This ensured conformity of the questionnaire to the methodological requirements before coding.

The empirical data coding and mathematical-statistical processing were done using SPSS and OCA software.

Table 1 outlines the main sociodemographic indicators of the research object (Table 1).

\section{Findings}

The survey revealed the respondents' attitude to IPR infringements. The answers to the question about the severity of this problem among the educational process participants are presented in Figure 1.

By and large, the IHE educators consider this problem to be rather acute, and those with own developments that require acquisition (protection) of rights as intellectual property assets perceive the problem more keenly.

Figure 2 shows how the survey viewed the problem in terms of its influence on their day-to-day activities.

To interpret this information applied to real life, we would like to calculate the correlation coefficient (Table 2) for the question "how acute do you find the problem of IPR infringement by the educational process participants?"

To determine the correlation between the attitude of the teaching staff from higher education to intellectual property and the level of influence on society and the opinion on the acuteness of the problem of infringement of intellectual property rights by participants in the educational process, it is necessary to calculate Spearman's coefficient. This correlation coefficient indicates how the teaching staff's attitudes to intellectual property are related to the problem of infringements in this area.

Similarly, the calculations were made for the opinion on the influence of the problem of IPR infringement on their day-to-day activities.

Now, let us give an example of Spearman's coefficient calculations for the selected opinion. These were done by the formula of Spearmen's rank-order correlation:

$$
r_{s}=1-\frac{6 \sum d^{2}}{n\left(n^{2}-1\right)},
$$

where $r_{s}$ is Spearmen's rank-order correlation; $d$ is the difference of rank pairs for the opinion; $n$ is the number of rank pairs (here: the number of the surveyed).

The results of the calculations the two questions previously mentioned are presented in Table 3.

To be able to evaluate how the described problems in intellectual property relate to the vital functions of society, interpreting the results obtained requires determining the limits for the calculated indicators. For the purposes of discussion, these limits are evaluated as follows:

strong connection $r_{s}$ is 0.7 or more

medium connection between 0.4 and 0.699

weak connection between 0 and 0.399

Thus, the results indicate a connection between the outlined problems, which is medium but closer to high. The educators in higher education believe the influence of IPR infringements on everyday life to be an acute problem.

As to the type of influence IPR infringements produce, the relative majority (48\%) consider it mostly negative. It is the owners of works and developments who mostly believe that the problem of human rights violations in this area needs to be addressed urgently and are more inclined to regard such impact as negative.

The respondents designate the responsibility for IPR protection primarily to the Council for Intellectual Property of the Cabinet of Ministers of Ukraine and the Ministry of Education and Science of Ukraine (see Table 4). However, there is no unanimity in the opinions as to who should own the responsibility for ensuring IPR protection, and there is a certain degree of scepticism about the role of the local education management bodies and media in this regard.

Another aspect surveyed was the causes and motives of IPR infringements (see Table 5). The answers received reveal that all the factors in Table 3 more or less equally correlate with the infringement problem.

The results obtained indicate a certain underestimation of the moral component of the problem. This assumption is conditioned by the number of votes given for the unwillingness/inability to create own intellectual products with preference to "borrowing" of the existing works of others (26\%) and the uncensorious attitude of the educational process participants to IPR infringements (21\%).

The educators with experience in acquisition (protection) of IPRs for their own developments associate IPR infringements with open access to information via internet more often than those with no such experience.

The survey results shed light on what tilts the balance in situations of the choice between infringing IPRs or not (see Table 6).

The answers reveal a relatively equal frequency for all the reasons listed previously, with the unawareness of the wrongdoing topping the list. This is also the reason most often given by the respondents with a positive experience in IPR acquisition (protection) and heads of structural divisions (deans, associate deans, and department heads).

As for QE in IPR acquisition, three quarters of the surveyed admit to having enhanced their skills over the past five years. They were the ones whose answers shed light on whether IPR protection is discussed (included) in QE programmes. Alarmingly, only every fifth respondent (21.5\%) had an opportunity to address IPR protection under their QE programme, while the overwhelming majority had no such opportunity (70\%) or had difficulty answering the question $(8.5 \%)$.

At the same time, these statistics closely correlate with the level of interest in improving the knowledge and skills in IPR protection, with $66 \%$ willing to improve their relevant knowledge and skills, $21 \%$ disinterested, and 13\% hesitant. A positive experience in IPR acquisition (protection) is often the underlying motivation behind the answers.

Yet, despite the high level of interest, the number of those who participate in QE programmes in IPR protection is rather insignificant (80\%) compared with those who do 
TABLE 1: Main sociodemographic indicators of research object.

\begin{tabular}{lr}
\hline Indicators & IHE teaching staff $(\%)$ \\
\hline Gender & \\
Women & 52 \\
Men & 48 \\
\hline Age (years) & \\
$20-29$ & \\
$30-39$ & 25 \\
$40-49$ & 26 \\
$50-59$ & 18 \\
60 and older & 22 \\
\hline
\end{tabular}

Pedagogical experience (in years)

Less than 1 year

$1-5$

6-15

$16-25$

30

More than 25 years

Work experience in this institution (in years)

Less than 1 year

\section{3}

$1-5$

$6-15$

$16-25$

More than 25 years

Administrative position

President, vice president/director, deputy director

$-3$

academic secretary of research and development

Dean, associate dean

Department head

2

16

4

Academic degree

Doctor of sciences

Candidate of sciences $(\mathrm{PhD})$

No degree

profile of disciplines taught

Technical, mathematical

48

Natural

14

Social sciences and the humanities

38

Ownership of works requiring acquisition (protection) of rights as IP assets

Have such works

Have no such works

31

Have experience in acquisition (protection) of IP rights for their own works

Positive experience

3

Negative experience

No experience

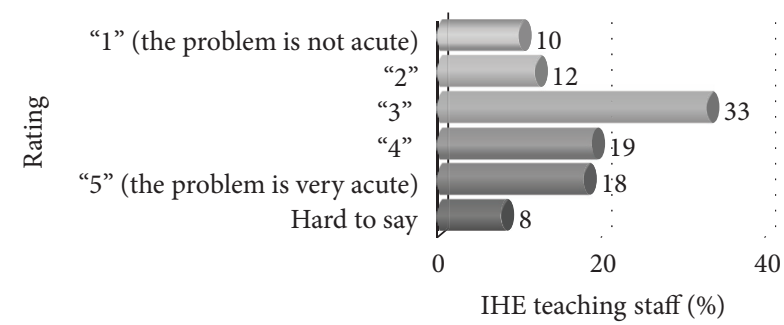

FIGURE 1: Level of acuteness of IPR infringement problem.

(20\%). The latter are mostly the owners of IP assets requiring copyright protection.

This unexpected dissonance finds explanation in the answers to the question about the motivation behind the

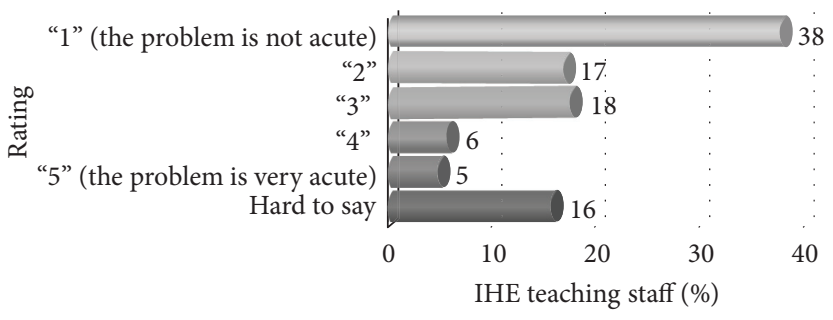

FIgURE 2: Level of IPR infringement influence on day-to-day activities.

decision to enhance IPR qualification and the most effective ways to do that (see Tables 7 and 8).

The findings reveal that the main factors behind the decision not to enhance the IPR qualification are self- 
TABLE 2: Results of calculations by the opinion on the acuteness of the problem of IPR infringement.

\begin{tabular}{|c|c|c|c|c|c|c|c|}
\hline Educator & Total & Opinion & Difference & Rank & Difference rank & Rank-order difference & Square of rank-order difference \\
\hline 1 & 8 & 5 & 3 & 164.5 & 144.5 & 20 & 400 \\
\hline 2 & 8 & 5 & 3 & 164.5 & 144.5 & 20 & 400 \\
\hline 3 & 8 & 5 & 3 & 164.5 & 144.5 & 20 & 400 \\
\hline 4 & 8 & 5 & 3 & 164.5 & 144.5 & 20 & 400 \\
\hline 5 & 8 & 5 & 3 & 164.5 & 144.5 & 20 & 400 \\
\hline 6 & 8 & 5 & 3 & 164.5 & 144.5 & 20 & 400 \\
\hline \multicolumn{8}{|l|}{$\ldots$} \\
\hline $\begin{array}{l}\cdots \\
175\end{array}$ & 1 & 0 & 1 & 7.5 & 68 & -60.5 & 3660.25 \\
\hline 176 & 1 & 0 & 1 & 7.5 & 68 & -60.5 & 3660.25 \\
\hline 177 & 1 & 0 & 1 & 7.5 & 68 & -60.5 & 3660.25 \\
\hline 178 & 1 & 0 & 1 & 7.5 & 68 & -60.5 & 3660.25 \\
\hline 179 & 0 & 0 & 0 & 7.5 & 15 & -7.5 & 56.25 \\
\hline \multirow[t]{2}{*}{180} & 0 & 0 & 0 & 7.5 & 15 & -7.5 & 56.25 \\
\hline & & & & Total & & & 337514.9 \\
\hline
\end{tabular}

TABLe 3: Spearmen's coefficient.

\begin{tabular}{lc}
\hline Opinion & Coefficient \\
\hline How acute do you find the problem of IPR infringement by the educational process participants? & 0.652752 \\
Does the problem of IPR infringement impact your day-to-day activities? & 0.659546 \\
\hline
\end{tabular}

TABLE 4: Distribution of responsibility for IPR protection.

\begin{tabular}{|c|c|c|c|}
\hline \multirow{2}{*}{ Question no. } & \multirow{2}{*}{ Indicators } & \multicolumn{2}{|c|}{ IHE teaching staff* } \\
\hline & & $\%$ & $\mathrm{R}$ \\
\hline 2 & Council on Intellectual Property of Cabinet of Ministers of Ukraine & 47 & 1 \\
\hline 1 & Ministry of Education and Science of Ukraine & 40 & 2 \\
\hline 15 & Owners of intellectual products & 25 & 3 \\
\hline 6 & Intellectual property inspectors & 22 & 4 \\
\hline 4 & Ministry of Justice of Ukraine & 16 & 5 \\
\hline 11 & Institutions of higher/secondary education & 15 & 6 \\
\hline 13 & Professional community (professional associations) & 13 & 7 \\
\hline 3 & Ministry of Economic Development and Trade of Ukraine & 9 & 8 \\
\hline 5 & Law-enforcement bodies & 8 & 9 \\
\hline 7 & Regional education management bodies & 7 & 10 \\
\hline 10 & Specialised IHE departments & 6 & 11 \\
\hline 14 & Specialised organizations (public, commercial) & 6 & 12 \\
\hline 8 & Local education management bodies & 4 & 13 \\
\hline 9 & Media & 3 & 14 \\
\hline 12 & Trade union & 3 & 15 \\
\hline 16 & Such institutions do not exist and to be created & 2 & 16 \\
\hline 17 & Hard to say & 9 & \\
\hline
\end{tabular}

* The percent can exceed $100 \%$ because more than one answer was allowed; the data presentation order depends on the number of votes given for a particular point.

assurance of having the sufficient level of the relevant knowledge and skills, lack of time, and overbureaucratization of the training process. The respondents with a positive experience in IPR acquisition (protection) and owners of IP assets tend to refuse from QE for lack of time as the main reason.

The respondents believe consultations from lawyers, experts, and colleagues with experience in the field, online courses or seminars, and educational events organized by IHEs or methodological centres to be more effective and therefore more attractive forms of professional development and literacy improvement in IPR protection. They find them most modern and in line with the requirements of the time. The least effective QE forms are short-term courses, 150hour courses, and, surprisingly, self-education.

The data in Table 9 indicates what authoritative bodies need to be in charge the teaching staff's QE, the most voted for are the Ministry of Education and Science of Ukraine, institutions of education, and the Council for Intellectual Property at the Cabinet of Ministers of Ukraine. At the same time, trade unions, specialised organizations, and local education management bodies are at the bottom of the list, 
TABLE 5: Reasons behind IPR infringements.

\begin{tabular}{|c|c|c|c|}
\hline \multirow{2}{*}{ Question no. } & \multirow{2}{*}{ Indicators } & \multicolumn{2}{|c|}{ IHE teaching staff* } \\
\hline & & $\%$ & $\mathrm{R}$ \\
\hline 1 & Open access to information via internet & 35 & 1 \\
\hline 2 & No relevant legal framework in the country & 31 & 2 \\
\hline 4 & $\begin{array}{l}\text { No penalty for } \\
\text { infringements of IP rights }\end{array}$ & 29 & 3 \\
\hline 5 & $\begin{array}{l}\text { Unwillingness/inability to create own intellectual products: why make } \\
\text { effort and create your own intellectual product if you can } \\
\text { "borrow" (take credit for) a product created by others }\end{array}$ & 26 & 4 \\
\hline 3 & Legal nihilism of educators & 23 & $5-6$ \\
\hline 7 & Low financial standing of the teaching staff, students & 23 & $5-6$ \\
\hline 6 & Uncensorious attitude to facts of IP rights infringements & 21 & 7 \\
\hline 8 & Hard to say & 7 & \\
\hline
\end{tabular}

* The percent can exceed $100 \%$ because more than one answer was allowed; the data presentation order (rank, R) depends on the number of votes given for a particular point.

TABLe 6: Attitudes to the problem of IP rights infringements.

\begin{tabular}{lr}
\hline Indicators & $\begin{array}{l}\text { IHE teaching } \\
\text { staff* }\end{array}$ \\
\hline $\begin{array}{l}\text { Persons infringing IP rights mostly lack understanding of their } \\
\text { infringements of any rights and particularly of the meaning of plagiarism, "piracy," etc. }\end{array}$ & 40 \\
The teaching staff have a neutral or tolerant attitude towards nonobservance of IP rights. & 51 \\
There is almost no use of technical tools in everyday educational practice to evaluate originality of texts, and therefore, \\
there is a risk of punishment for plagiarism is minimal. & 36 \\
Infringements of IP rights arise from overload, race against time, need to complete a significant number of tasks in a short time. \\
$\begin{array}{l}\text { The teaching staff mostly do } \\
\text { not see themselves as authors of works to be protected as IP assets. }\end{array}$ & 39 \\
\hline
\end{tabular}

"Column " 1 " is the sum of "I agree" and "I rather agree"; column " 2 " is the sum of "I disagree" and "I rather disagree"; the sum of " 1 " and "2" can be less than $100 \%$ because the "hard to say" answers are not presented.

TABLE 7: Motivations for qualification enhancement.

\begin{tabular}{|c|c|c|c|}
\hline \multirow[t]{2}{*}{ Question no. } & \multirow[t]{2}{*}{ Indicators } & \multicolumn{2}{|c|}{$\begin{array}{c}\text { IHE } \\
\text { teaching } \\
\text { staff* }\end{array}$} \\
\hline & & $\mathrm{R}$ & $\%$ \\
\hline 1 & I consider my level of qualification in protection of IP rights and academic integrity to be sufficient. & 1 & 28 \\
\hline 3 & I do not have enough time. & 2 & 23 \\
\hline 5 & The process is too bureaucratic. & 3 & 20 \\
\hline 2 & I am not sure if I need it because I see no sense in protecting intellectual rights on my products. & 4 & 15 \\
\hline 6 & Existing QE forms are not effective. & 5 & 12 \\
\hline 4 & It requires money infusions. & 6 & 10 \\
\hline
\end{tabular}

*The percent can exceed $100 \%$ because more than one answer was allowed; the "hard to say" answers are not included; the data presentation order (rank, $\mathrm{R}$ ) depends on the number of votes given for a particular point.

which indicates lack of trust to these institutions in terms of their role in and impact on professional development of the teaching staff.

Regarding managing IPR protection, it is important to clarify the factors and mechanisms for improvement. Table 10 provides suggestions as to how to make IPR protection more effective.

As to what could increase the level of IPR protection, the vast majority consider this to be a consistent state policy on IPR protection. The respondents with positive experience in
IPR acquisition (protection) are more numerous in being of this opinion. The second most important factor is cultivation of an intolerant attitude to IPR infringements. Again, those with the relevant personal experience are more numerous here. The third in this ranking is the importance of legal mechanisms, including legislation modernization, legal support, and punishment for IPR infringements. Interestingly, media involvement, introduction of intellectual property related disciplines, explanatory, and educational work are believed least effective. 
TABLE 8: Effective forms of enhancement of qualification and literacy in IPR protection.

\begin{tabular}{|c|c|c|c|}
\hline \multirow[t]{2}{*}{ Question no. } & \multirow[t]{2}{*}{ Indicators } & \multicolumn{2}{|c|}{$\begin{array}{l}\text { IHE teaching } \\
\text { staff* }\end{array}$} \\
\hline & & $\mathrm{R}$ & $\%$ \\
\hline 4 & Individual consultations from lawyers, IP experts, colleagues with experience in protection of IP rights & 1 & 39 \\
\hline 6 & Electronic, network, online courses & 2 & 32 \\
\hline 1 & Educational and methodological seminars, conferences organized by IHE/educational and teaching centres & 3 & 27 \\
\hline 2 & A seminar (two-hour)/methodological seminar at school, trainings & 4 & 24 \\
\hline 7 & Self-education & 5 & 21 \\
\hline 5 & A complete QE course enhancement (150 hours) & 6 & 15 \\
\hline 3 & A short-term course (up to 1 week) & 7 & 14 \\
\hline 8 & Hard to say & & 8 \\
\hline
\end{tabular}

* The percent can exceed $100 \%$ because more than one answer was allowed; the data presentation order (rank, R) depends on the number of votes given for a particular point.

TABLE 9: Distribution of responsibility for teaching staff's qualification enhancement in IPR protection.

\begin{tabular}{|c|c|c|c|}
\hline \multirow[t]{2}{*}{ Question no. } & \multirow[t]{2}{*}{ Indicators } & \multicolumn{2}{|c|}{$\begin{array}{c}\text { IHE teaching } \\
\text { staff* }\end{array}$} \\
\hline & & $\mathrm{R}$ & $\%$ \\
\hline 1 & Ministry of Education and Science of Ukraine & 1 & 41 \\
\hline 9 & An institution of higher/secondary education & 2 & 37 \\
\hline 2 & Council for intellectual property (advisory body of the cabinet of ministers of Ukraine) & 3 & 32 \\
\hline 13 & Teaching staff themselves & 4 & 18 \\
\hline 8 & Specialised departments of IHE & 5 & 12 \\
\hline 4 & Ministry of Justice of Ukraine & 6 & 11 \\
\hline 5 & IP inspectors & 7 & 10 \\
\hline 11 & Professional community (professional associations) & 8 & 10 \\
\hline 3 & Ministry of Economic Development and Trade of Ukraine & 9 & 8 \\
\hline 6 & Regional education management bodies & 10 & 5 \\
\hline 7 & Local education management bodies & 11 & 4 \\
\hline 12 & Specialised organizations (public, commercial) & 12 & 4 \\
\hline \multirow[t]{2}{*}{10} & Trade union & 13 & 2 \\
\hline & Hard to say & & 9 \\
\hline
\end{tabular}

*The percent can exceed $100 \%$ because more than one answer was allowed; the $<2 \%$ answers are not presented; the data presentation order (rank, $\mathrm{R}$ ) depends on the number of votes given for a particular point.

TABLE 10: Factors enhancing IPR protection.

\begin{tabular}{|c|c|c|c|}
\hline \multirow[t]{2}{*}{ Question no. } & \multirow[t]{2}{*}{ Indicators } & \multicolumn{2}{|c|}{$\begin{array}{c}\text { IHE } \\
\text { teaching } \\
\text { staff* }^{*}\end{array}$} \\
\hline & & $\mathrm{R}$ & $\%$ \\
\hline 1 & Consistent state policy in protection of IP rights & 1 & 61 \\
\hline 7 & Cultivation in society of intolerance towards facts of infringements of IP rights & 2 & 38 \\
\hline 3 & Updates in legislation, legal support & 3 & 30 \\
\hline 4 & Punishment for infringements of IP rights & 4 & 27 \\
\hline 2 & Demanding administrators of educational institutions & $5-6$ & 21 \\
\hline 8 & Explanatory, educational work & $5-6$ & 21 \\
\hline 5 & Media support: coverage, promotion of IP rights on television, in the press, etc. & 7 & 19 \\
\hline 6 & Integration of IP disciplines in educational programmes for training of specialists at institutions of higher education & 8 & 17 \\
\hline
\end{tabular}

*The percent can exceed $100 \%$ because more than one answer was allowed; the "hard to say" and $<2 \%$ answers are not presented.

Table 11 shows that only about every third of the IHE teaching staff believe that IHE administrators are making significant efforts to protect IPRs, while almost twice as many are convinced that such efforts need to be made by
IHE administrations. Alarmingly, 75\% find their IHE administrators' role in this process insufficient.

An emphasis on cultivation of a culture of intellectual property protection is in part addressed in Table 11, in 
TABLE 11: Role of administrators of educational institutions in IPR protection management.

\begin{tabular}{|c|c|c|}
\hline Indicators & $\begin{array}{c}\text { None so } \\
\text { far } \\
(\%)\end{array}$ & $\begin{array}{c}\text { Has to } \\
\text { be } \\
(\%)\end{array}$ \\
\hline Perceptible and significant: the administrators are making significant efforts to protect IP rights of teachers & 35 & 64 \\
\hline $\begin{array}{l}\text { Hardly perceptible, sporadic: such matters issues are sometimes discussed at IHE meetings; decisions are approved, } \\
\text { but real changes are imperceptible }\end{array}$ & 27 & 13 \\
\hline Imperceptible: the administrators may be doing something about protecting IP rights, but I do not feel it & 17 & 7 \\
\hline Hard to say & 21 & 16 \\
\hline
\end{tabular}

particular, when it comes to the potential that introducing intellectual property disciplines into IHE training programmes could have in encouraging improvements in protection of such rights. Two thirds $(68 \%)$ believe their IHEs teach such a discipline.

Answering the question if their educational institutions practise concluding agreements with the teaching staff on distribution of copyright to their intellectual product (Figure 3), almost half of the respondents (46\%) could not answer the question, and only about a third (32\%) confirmed the existence of such practice. The remaining $21 \%$ believe that everything is either the property of the institution or the author.

When asked about instances where their colleagues exercised IPRs for commercial gain, the vast majority (81\%) were aware of none, which probably indicates that this practice is not currently widespread.

Considering the previously mentioned, the results of the study indicate the importance and necessity of developing a competence in IPR in the IHE teaching staff as part of QE courses. With this in mind, we would like to suggest a technology for such qualification enhancement taking into account the subject area of the professional activity and the main types of intellectual property that constitute results of their activities. This is important to ensure high learning outcomes in students' self-study under QE courses and during their further professional activity.

The proposed technology (Figure 4) is a complex process consisting of four interrelated stages: (1) organizationalpreparatory; (2) motivational-targeted; (3) cognitive, (4) operational-activity; (5) control-evaluation.

The organizational-preparatory stage sets the goals and objectives of the $\mathrm{QE}$ course, prepares educational and methodological literature, develops thematic training plans, determines the course duration (from one to six credits depending on the need), and so on. When preparing a $\mathrm{QE}$ course programme, it is necessary to account for the peculiarities of group formation, primarily by the following factors:

(1) The level of knowledge, skills and abilities acquired by the students (low, sufficient, and high)

(2) Inquiries about the form of education (distance, fulltime, mixed, and individual lessons)

(3) The practical significance of the knowledge acquired

The previously mentioned ensures the most effective assimilation and application of the knowledge to satisfaction of the interests of different categories of IHE teaching community in receipt of quality educational services. This is the main factor in cultivation of their interest in qualification enhancement in IP, which will create the preconditions for dealing with legal nihilism in this area and improve the level of professional ethics.

This stage also provides preliminary diagnostics by assessing the knowledge in future QE students. This can employ various tools, including testing, questionnaires, and practical cases. Such diagnostics should be carried out in several stages, conditioned by the need to form groups according to the level of knowledge. The first stage here is a questionnaire; the second stage is testing in the theoretical fundamentals; the third stage is solving a case. The results of each stage are assessed separately and used to form the groups. Preliminary diagnostics also includes determining the best suited form of learning.

The motivational-targeted stage includes activities on the need and importance of the IP competence development in the IHE teaching staff for their further professional activity, introducing innovative teaching methods to motivate the teaching staff to acquire an IP competence in QE courses. The interest in $\mathrm{QE}$, as the previously mentioned study reveals, is expressed by the majority of the respondents. Motivation does not mean merely imparting the ready-made motives and goals to the students; rather, it means placing them under the conditions and in situations that would require them to develop the desired motives and goals in relation to their experience, individuality, and inner convictions [33].

The purpose of qualification enhancement in IP is cultivation of knowledge, skills, abilities, and professionally important qualities necessary to ensure the quality of their professional duties, educational services, and public policy reforms in the field of education. This stage includes motivational lectures and discussions to substantiate the importance and necessity of building this competence.

The cognitive stage aims to improve the IP content of the QE programme, which needs to take into account the needs of the teaching staff with regard to the peculiarities of their professional activities and the level of their training. We believe that such QE programmes should include the following: (1) fundamentals of intellectual property; (2) legal protection of individual intellectual property objects (depending on the subject area); (3) observance of academic integrity rules. Correction and specification thereof rely on the results obtained in at the previous stages of the pedagogical technology. 


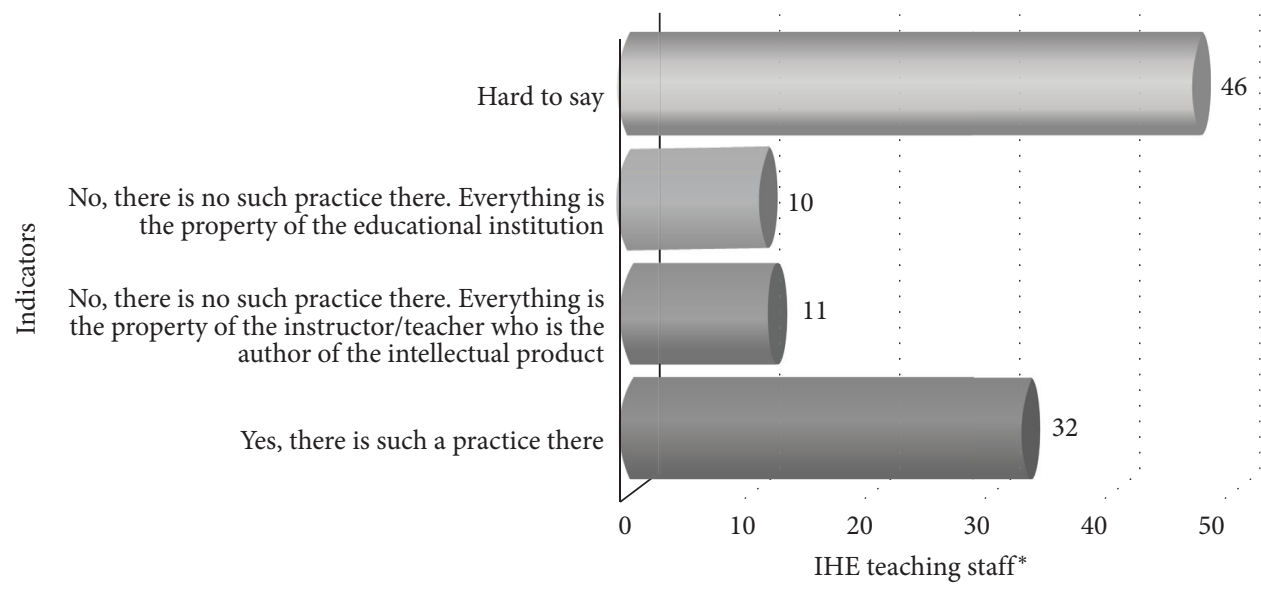

Figure 3: Practices of copyright agreements on intellectual products. *The percent can be less than $100 \%$ because the "other" answers are not included.

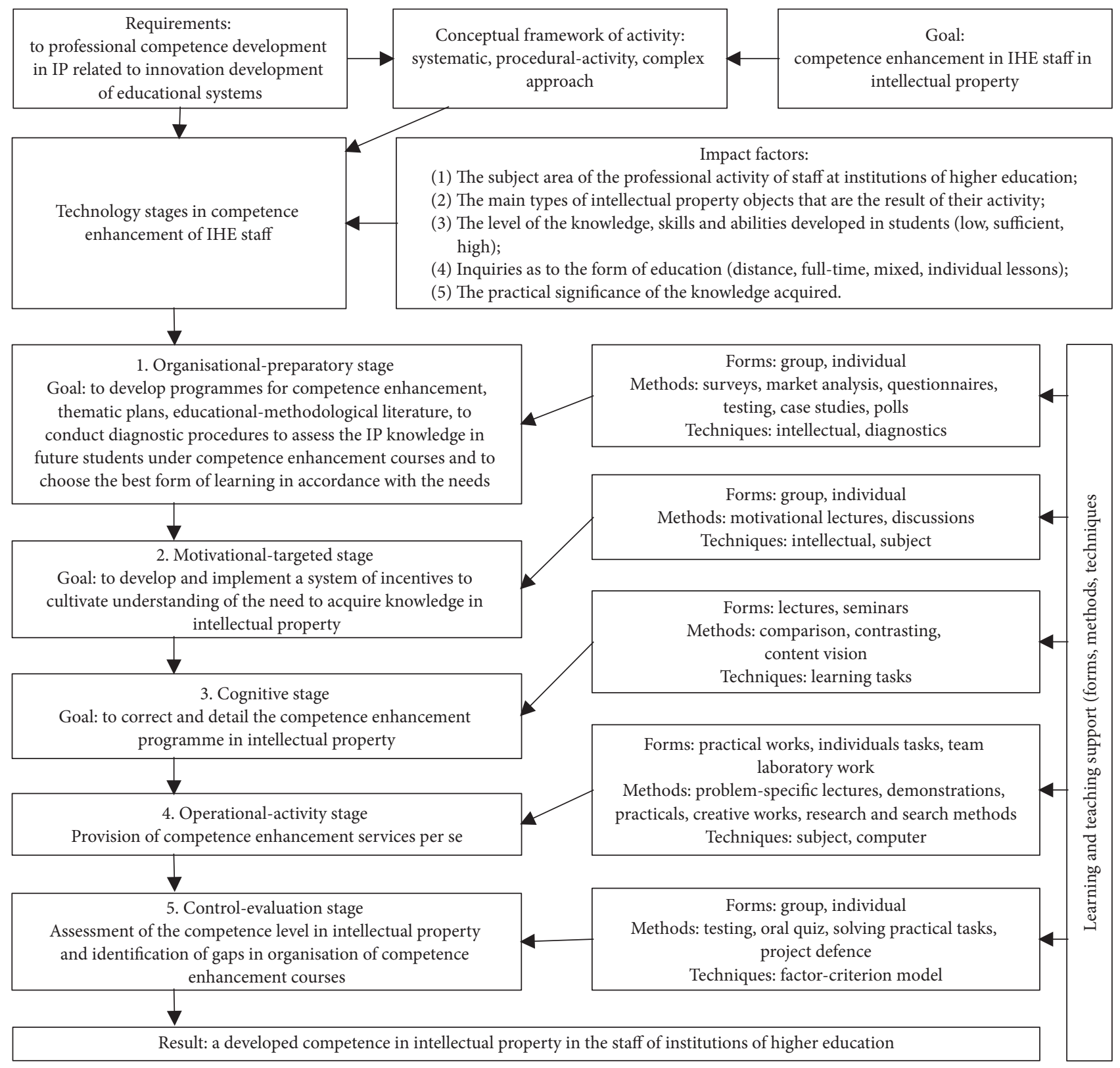

FIGURE 4: Model of QE technology for the IHE staff. 
The operational-activity stage is the main in the model, where direct provision of QE services takes place. Based on the diagnostics results and in compliance with the chosen form of education, theoretical and practical classes are conducted, educational and methodological literature is lent, consultations and trainings are held, and individual support for students' self-study is provided.

The control-evaluation stage is intended to assess the IP competence acquired. Its results are also important for revealing gaps in the $\mathrm{QE}$ course organization. At this stage, the students' knowledge is checked using the following tools: real-time testing, defence of a project on a selected topic, preparation of the documents required to obtain a title of protection for the selected intellectual property object, and so on. Interviews with students are also important to identify their further professional needs. Qualimetry tools are actively used, too, to develop factor-criteria models to assess the level of professional competence in IPR protection and exercise.

\section{Discussion}

An effective way to address the problem under study is to develop educational programmes for $\mathrm{QE}$ courses that will take into account the area of the students' professional activity. The general part of the QE programmes for the IHE teaching staff should cover creation and dissemination of copyright objects, their protection and execution, and the general issues of IPR execution and protection. The variable part of the programme, in our opinion, should address the specific aspects of exercise and protection of copyright and related rights depending on the speciality of the IHE teaching staff. Moreover, given the low level of the IHE's intellectual capital use and lack of the relevant competence in the IHE administrators and staff, it is vital to include trainings in technology transfer and commercialization of the corresponding IHE intellectual capital in the QE course programmes.

To deal with the legal nihilism related to IPR observance, it is essential that QE programmes should include modules aimed at developing a competence in IPR protection and exercise. The requirement of the time also lies in holding seminars, workshops, online trainings, and field internships on the corresponding topics intended to improve the situation with IPR protection and exercise in Ukraine and to cultivate the relevant culture in its people.

An important step on the part of the state needs to be further implementation of a consistent policy in IPR protection and cultivation of an intolerant attitude to IPR infringements in Ukraine. Bearing this in mind, the strategy in this area has to take into account the need for mass IPR qualification enhancement among IHE teaching staff and administrators while aiming to cultivate the relevant culture in IHE graduates.

The higher education standards need reviewing for IPR competence development in IHE graduates as an important learning outcome.

Prospective areas of research are theoretical-methodological substantiation of the technology for cultivation of a competence in intellectual property rights protection among the educators in higher education during their qualification enhancement. This technology is to comprise the following stages: organizational-preparatory; motivational-targeted; cognitive; operational-activity; control-evaluation. The performance of the technology will be determined using the qualimetry method. This will help develop the professional competence in intellectual property more effectively.

The main limitations in the application of the proposed technology are related to the fact that today's system of higher education is under reformation. This entails constant changes in the legislation, which negatively affects the possibility of implementation of the proposed model in practice. Moreover, it should be mentioned that the awareness of teaching staff at institutions of higher education of matters related to intellectual property is insufficient, which raises the need to enhance their qualification in this field. However, practice shows that a few of them are quite competent in this field and can therefore ensure teaching of the corresponding disciplines in intellectual property rights protects during qualification enhancement programmes.

An important aspect is overcoming the low level of awareness in intellectual property is inclusion of the relevant disciplines in the curricula of professionals in various majors. However, this requires additional hours for the corresponding discipline, which is often problematic for realization due to the teaching and learning overload.

\section{Conclusions}

The intellectual property qualification enhancement among the educators in higher education has been discussed at conferences and forums, in particular, at the 2020 Forum on Development of the Unified Open Information Space in Lifelong Education under the section on professional development of educators in intellectual property [34].

Since the majority of the surveyed lack awareness of practices of concluding agreements on copyright division for the intellectual product they have created, or the possibility of exercising their rights in intellectual property to obtain commercial profit, it is important to inform the educators in higher education about their rights for the intellectual property assets they create and about the commercial benefits they are entitled to.

Administrators of institutions of higher education need to take effort to organise intellectual property rights protection at their institutions to prevent a considerable body of problems that are at the core of emergence of violations, in particular, the teaching staff's overload, the need to complete a considerable number of tasks on a tight schedule, legal nihilism, and so on. The availability of the relevant information awareness will also help improve the situation with academic integrity at institutions of higher education and the functioning of the internal systems of education quality assurance.

An important constituent in further development of the generation is an intellectual product. In this regard, knowledge in IPR exercise and protection is becoming more and more relevant as a prerequisite for creation of a 
favourable environment for intellectual activity development, which directly impacts the rate of national economic development. An important role in this process belongs to the IHE teaching staff, whose activity is primarily intellectual and creative and serves as the foundation for development of all the spheres in the society. Therefore, their qualification enhancement by shaping their competence in IPR protection and exercise needs to become an important direction in implementation of the education reform in Ukraine.

The vast majority of IHE teaching staff do not enhance their qualification in intellectual property, although they are willing to do it. The negative point here is lack of integration of knowledge in IPR exercise and protection in the related areas during $\mathrm{QE}$ courses, which requires urgent attention and review of the $\mathrm{QE}$ process for the teaching staff in various specialities. Moreover, the need to change the approaches to $\mathrm{QE}$ is important because the main demotivating factor for undertaking QE is overbureaucratization of the process and lack of time due to the workload.

The proposed QE model can facilitate the QE process and therefore ensure better quality of the teaching staff's professional duties and educational services in general.

\section{Data Availability}

The data supporting the results of this study are available from the corresponding author upon request.

\section{Conflicts of Interest}

The authors declare that there are no conflicts of interest regarding the publication of this paper.

\section{Acknowledgments}

This study presents the results of a pilot sociological survey "intellectual property through the eyes of educators" conducted by the Department of Creative Pedagogy and Intellectual Property of the Ukrainian Engineering Pedagogics Academy in Cooperation with the Sociologists of V.N. Karazin Kharkiv National University under the state-funded R\&D topic no. 19-01 DB "theoretical and methodological foundations of $\mathrm{QE}$ of the teaching staff of the education system in the field of intellectual property."

\section{References}

[1] O. M. Storozhenko and O. B. Nimko, "Vykladannia dystsypliny Intelektualna vlasnist $\mathrm{u}$ vyshchykh navchalnykh zakladakh [Teaching Intellectual Property subject in institutions of higher education]," Osv Dyskurs, vol. 1, no. 3, pp. 177-184, 2011.

[2] I. G. Becker, Human Capital: Theoretical and Empirical Analysis with Special Reference to Education, p. 390, National Bureau of Economic Research, Cambridge, UK, 1993.

[3] Office of the United State Trade Representative, "USTR releases annual special 301 report on intellectual property protection and review of notorious markets for counterfeiting and piracy," 2020, https://ustr.gov/about-us/policy-offices/ press-office/press-releases/2020/april/ustr-releases-annual- special-301-report-intellectual-property-protection-andreview-notorious.

[4] O. P. Orliuk, "Osvita z intelektualnoi vlasnosti u systemi vyshchoi osvity Ukrainy: problemy ta zavdannia [Education in intellectual property in the higher education system in Ukraine]," Teor I Prakt Intelekt Vlasnosti, no. 6, pp. 148-159, 2019.

[5] V. V. Oliinyk, "Profesiine udoskonalennia naukovo-pedahohichnykh pratsivnykiv: problemy ta shliakhy vyrishennia [Professional improvement of the academic staff: problems and solutions]," Probl Ta Perspekt Formuvannia Natsionalnoi Humanit Elit, vol. 27, no. 31, pp. 88-97, 2010.

[6] S. V. Kornovenko, O. A. Kulbashna, and O. S. Paramonova, Pravo Intelektualnoi Vlasnosti Naukovo-Pedahohichnoho Pratsivnyka [An Academic's Intellectual Property Right], p. 328, Bohdan Khmelnytsky National University of Cherkasy, Cherkasy, Ukraine, 2016.

[7] O. O. Isaienko, Upravlinnia Pravovym Zakhystom Rezultativ Intelektualnoi Diialnosti Naukovo-Pedahohichnykh Pratsivnykiv Pisliadyplomnoi Pedahohichnoi Osvity [Managing Legal Protection of the Results of the Academic Staff's Activity in Posgraduate Pedagogical Education], Bohdan Khmelnytsky National University of Cherkasy, Cherkasy, Ukraine, 2016.

[8] N. P. Korohod, "Intelektualna vlasnist u systemi upravlinnia rezultatamy naukovoi ta innovatsiinoi diialnosti VNZ [Intellectual property in the system of management of IHE scientific and innovation activity results]," SShA Jkonomyka Polytyka Ydeolohyia, no. 1, pp. 52-64, 1991.

[9] T. O. Redchyts, "Problemy obiznanosti pedahohiv u sferi dotrymannia avtorskykh prav $\mathrm{v}$ informatsiino-osvitnomu prostori [Problems of awareness of educators in observance of copyright in the information-educational space]," Informatsiini tekhnolohii i zasoby navchannia, vol. 5, no. 25, , 2011, https://journal.iitta.gov.ua/index.php/itlt/article/download/ $568 / 448$.

[10] V. E. Luniachek and N. P. Ruban, "Pratsivnyk osvity iak subiekt intelektualnoi vlasnosti [Education worker as an agent of intellectual property]," Upravlinnia Iakistiu V Osviti Ta Promyslovosti: Dosvid, Problemy Ta Perspektyvy, pp. 99-101, 2017.

[11] M. I. Lazariev, V. E. Luniachek, N. P. Ruban, V. M. Timaniuk, N. S. Fesenko, and Y. Y. Chernenko, "Upravlinnia pidhotovkoiu fakhivtsiv u sferi intelektualnoi vlasnosti: transformatsii na suchasnomu etapi [Managing specialists' training in IP: transformations at the current stage]," Aktual Probl derzhavnoho Upr, vol. 1, no. 51, , 2017, http://www.kbuapa. kharkov.ua/e-book/apdu/2017-1/doc/5/01.pdf.

[12] V. E. Luniachek, "Kompetentnisna model vypusknyka mahistratury - fakhivtsia v sferi intelektualnoi vlasnosti [Competence model of an MS programme graduate - an expert in intellectual property]," Probl Inzhenerno-Pedahohichnoi Osv.vol. 54, pp. 34-46, 2017.

[13] V. Luniachek and T. Varenko, "Postgraduate pedagogical education in Ukraine," Urban Studies and Public Administration, vol. 1, no. 2, pp. 199-209, 2018, http://www.scholink. org/ojs/index.php/uspa/article/view/1559.

[14] S. V. Tolochko, "Intehralna kompetentnist pedahohichnoho ta naukovo-pedahohichnoho personalu dlia systemy pisliadyplomnoi pedahohichnoi osvity [Integral competence of the teaching and academic staff for the postgraduate pedagogical education system]," Sci Pedagog Educ, vol. 1, no. 28, pp. 22-29, 2019.

[15] Department for Transition and Developed Countries, "Teaching intellectual property (IP) in countries in transition 
2013,” 2013, https://www.wipo.int/publications/en/details. jsp?id=4115\&plang=EN.

[16] O. Kashyntseva, "Avtorske pravo na naukovyi tvir u sferi medytsyny: etychni ta tvorchi aspekty vynyknennia [Copyright to a literary work in medicine: ethical and creative aspects of emergence]," Teor I Prakt Intelekt Vlasnosti, vol. 6, pp. 16-26, 2013.

[17] I. Komarnytska, "The rights of intellectual property to scientific-pedagogical activities and their protection," Visnik Nacional'nogo Universitetu Lvivska Politehnika. Seria: Uridicni Nauki, vol. 6, no. 22, pp. 174-179, 2019.

[18] R. B. Shyshka, Okhorona Prava Intelektualnoi Vlasnosti: Avtorsko-Pravovyi Aspekt [Protection of Intellectual Property Right: Author-Legal Aspect], p. 368, Kharkiv National University of Internal Affairs, Kharkiv, Ukraine, 2002.

[19] Y. S. Yepifanova, Avtorski Prava Naukovo-Pedahohichnykh Pratsivnykiv Vyshchykh Navchalnykh Zakladiv [Copiright of the Academic Staff of Institutions of Higher Education], p. 16, Kharkiv National University of Internal Affairs, Kharkiv, Ukraine, 2010.

[20] A. N. A. Alkhateeb, L. Yao, and J. K. Cheng, "Intellectual capital practices' in universities," in Proceedings of the International Conference on Economy, Social and Technology, Pahang, Malaysia, March 2018, https://www.researchgate.net/ publication/324122452_INTELLECTUAL_CAPITAL_ PRACTICES\%27_IN_UNIVERSITIES.

[21] R. Soetendorp, "Developing the curriculum for collaborative intellectual property education," Journal of Information, Law Technology, vol. 1, 2006, https://warwick.ac.uk/fac/soc/law/ elj/jilt/2006_1/soetendorp/soetendorp.pdf.

[22] R. Najafov, "Issues of forming culture of intellectual property," Azərbaycan Məktəbi.vol. 6, no. 81, pp. 47-54, 2017.

[23] T. Ogiya, H.-H. Uchida, T. Kimura, K. Sugimitsu, and C. Tamura, "Education, dissemination and raising the awareness of intellectual property in Japan," APIC Japan, vol. 23, p. 276, 2018, https://www.jpo.go.jp/e/news/kokusai/ developing/training/textbook/document/index/Education. pdf.

[24] M. A. P. Amparado and A. C. Miro, "Intellectual property: are faculty members aware of their rights?" Cebu Journal Computer Study, vol. 2, no. 2, 2019.

[25] J. Villasenor, "Fee-Shifting" and Patent Reform: A DoubleEdged Sword for Start-Up Companies, Forbes, Hong Kong, China, 2013.

[26] "Draft of the national strategy for intellectual property development in ukraine for 2020-2025," 2019, https://drive. google.com/file/d/1oqjabxZiTempwJjaZsO1NoLt7fvP_qxj.

[27] Ministry of Education and Science of Ukraine, Mon Ta YEP Orhanizovuiut Treninh Rozvytku Pidpryiemnytskoi Osvity [MES and YEP to Organise Trainings for Development of entrepreneurial education], Ministry of Education and Science of Ukraine, Kyiv, Ukraine, 2018, https://mon.gov.ua/ua/news/ mon-ta-yep-organizovuyut-trening-z-rozvitkuakademichnogo-pidpriyemnictva-vidkrito-reyestraciyu-dlyauchasnikiv.

[28] V. Luniachek, A. Brovdii, O. Kulakovskyi, and T. Varenko, "Academic integrity in higher education of Ukraine: current state and call for action," Education Research International, vol. 20208 pages, 2020.

[29] L. Starkey, S. Corbett, A. Bondy, and S. Davidson, "Intellectual property: what do teachers and students know?" International Journal of Technology and Design Education, vol. 20, no. 3, pp. 333-344, 2010, https://www.researchgate.net/publication/
225535221_Intellectual_ property_What_do_teachers_and_ students_know.

[30] National Union of Students, "Student attitudes towards intellectual property," 2012, https://www.nus.org.uk/PageFiles/ 12238/2012_NUS_IPO_IPAN_Student_Attitudes_to_ Intellectectual_Property.pdf.

[31] S. O’Sullivan, M. Friebe, W. R. Tonti et al., "Surveyed impact of intellectual property training in STEM education on innovation, research, and development," The Journal of World Intellectual Property, vol. 23, no. 5-6, pp. 658-678, 2020.

[32] Ukrainian Engineering Pedagogics Academy, "Intellectual property through the eyes of education workers (by the results of the sociological survey (code dk-021:2015-97320000-3) in accordance with agreement no.87-ii as of 27.05.2019): analytical report," 2019, http://t.ly/mrXf.

[33] A. K. Markova and T. A. Matis, Formirovanie Motivatsii Ucheniya [Development of Learning Motivation]: Teacher's Book, 1990.

[34] "The Development of the Unified Open Information Space in Lifelong Education "Forum-SOIS, 2020," 2020, http://lib.iitta. gov.ua/id/eprint/720152. 